\title{
Developing Earthquake-Resistant Structural Design Standard for Malaysia Based on Eurocode 8: Challenges and Recommendations
}

\author{
Daniel T. W. Looi ${ }^{1, *(D)}$, Nelson Lam ${ }^{2}$ and Hing-Ho Tsang ${ }^{3(\mathbb{D}}$ \\ 1 Faculty of Engineering, Computing and Science, Swinburne University of Technology, Kuching 93350, \\ Malaysia \\ 2 Department of Infrastructure Engineering, The University of Melbourne, Melbourne, VIC 3010, Australia; \\ ntkl@unimelb.edu.au \\ 3 School of Engineering, Swinburne University of Technology, Melbourne, VIC 3122, Australia; \\ htsang@swin.edu.au \\ * Correspondence: dlooi@swinburne.edu.my
}

Citation: Looi, D.T.W.; Lam, N.;

Tsang, H.-H. Developing

Earthquake-Resistant Structural

Design Standard for Malaysia Based on Eurocode 8: Challenges and Recommendations. Standards 2021, 1, 134-153. https://doi.org/10.3390/ standards1020012

Academic Editor: Humberto Varum

Received: 9 October 2021

Accepted: 26 October 2021

Published: 1 December 2021

Publisher's Note: MDPI stays neutral with regard to jurisdictional claims in published maps and institutional affiliations.

Copyright: (C) 2021 by the authors Licensee MDPI, Basel, Switzerland. This article is an open access article distributed under the terms and conditions of the Creative Commons Attribution (CC BY) license (https:// creativecommons.org/licenses/by/ $4.0 /)$.

\begin{abstract}
In late 2017, the Malaysian National Annex (NA) to Eurocode 8 (EC8) was released and enacted following some 13 years of deliberations and preparations. The authors of this paper aim to use this article to share their experiences and reflections during this period of developing the first national standard for the seismic design of buildings for Malaysia. To begin with, there were major challenges in implementing the 20-year-old EC8 framework for a country so far away from Europe. The first challenge was adapting the probabilistic seismic hazard assessment (PSHA) methodology in a low-to-moderate seismicity region where the paucity of representative seismic data presented a great deal of uncertainties. To address this situation, imposing a minimum level of seismic hazard was recommended. The second challenge was about dealing with the outdated EC8 site classification scheme, which poorly represents the potential effects of soil amplification in certain geological settings. To address this situation, an alternative site classification scheme in which the site natural period is an explicit modelling parameter was introduced. The third challenge was concerned with difficulties generated by the EC8 provisions mandating Ductility Class Medium (DCM) detailing in certain localities where the level of seismic hazard is predicted to exceed a certain threshold. To address this situation, the viable option of using strength to trade off for ductility was recommended, or in cases where ductility design is needed, a simplified set of code-compliant DCM designs was presented. The fourth challenge was about handling the requirements of EC 8 that the majority of buildings are to involve dynamic analysis in their structural design when the majority of practising professionals did not have the skills of exercising proper use of the requisite software. To address this situation, a generalized force method was introduced to control the use dynamic analysis in commercial software. It is hoped that, through sharing the lessons learnt, code drafters for the future would be able to find ways of circumventing the multitude of challenges with clear thinking and pragmatism.
\end{abstract}

Keywords: Eurocode 8; PSHA; site period parameterisation; DCM detailing; dynamic analysis; low-to-moderate seismicity regions

\section{Introduction}

Malaysia enacted its first national code of practice for the seismic design of buildings following the release of the Malaysian National Annex (NA) of Eurocode 8 (EC8, or officially named as MS EN1998-1) in late 2017 [1,2]. The authors were among the most active handson participants in the preparation of the standard since 2008. This paper is written to present the experience and reflections of the authors gained during this period of standard writing. To begin with, the authors encountered major challenges in the drafting of the NA 
for Malaysia where practising structural design professionals had no prior seismic design experience. This problem was compounded by the distance of Malaysia from the European continent. Whilst some of the challenges were presented briefly in a regional conference [3], this paper presents an opportunity to discuss the key issues elaborated.

There are many facets of activities that are related to the endeavour of standard drafting. To put the readers into context, Figure 1 presents a collated summary of the relevant key activities in chronological order since 2004. A detailed listing of the individual activities can be found in Appendix A. Broadly speaking, there were three phases in the development of the Malaysia NA to EC8 [2], namely, the pre-standard phase (of awakening and preparation), the standard-writing phase and the post-standard phase.

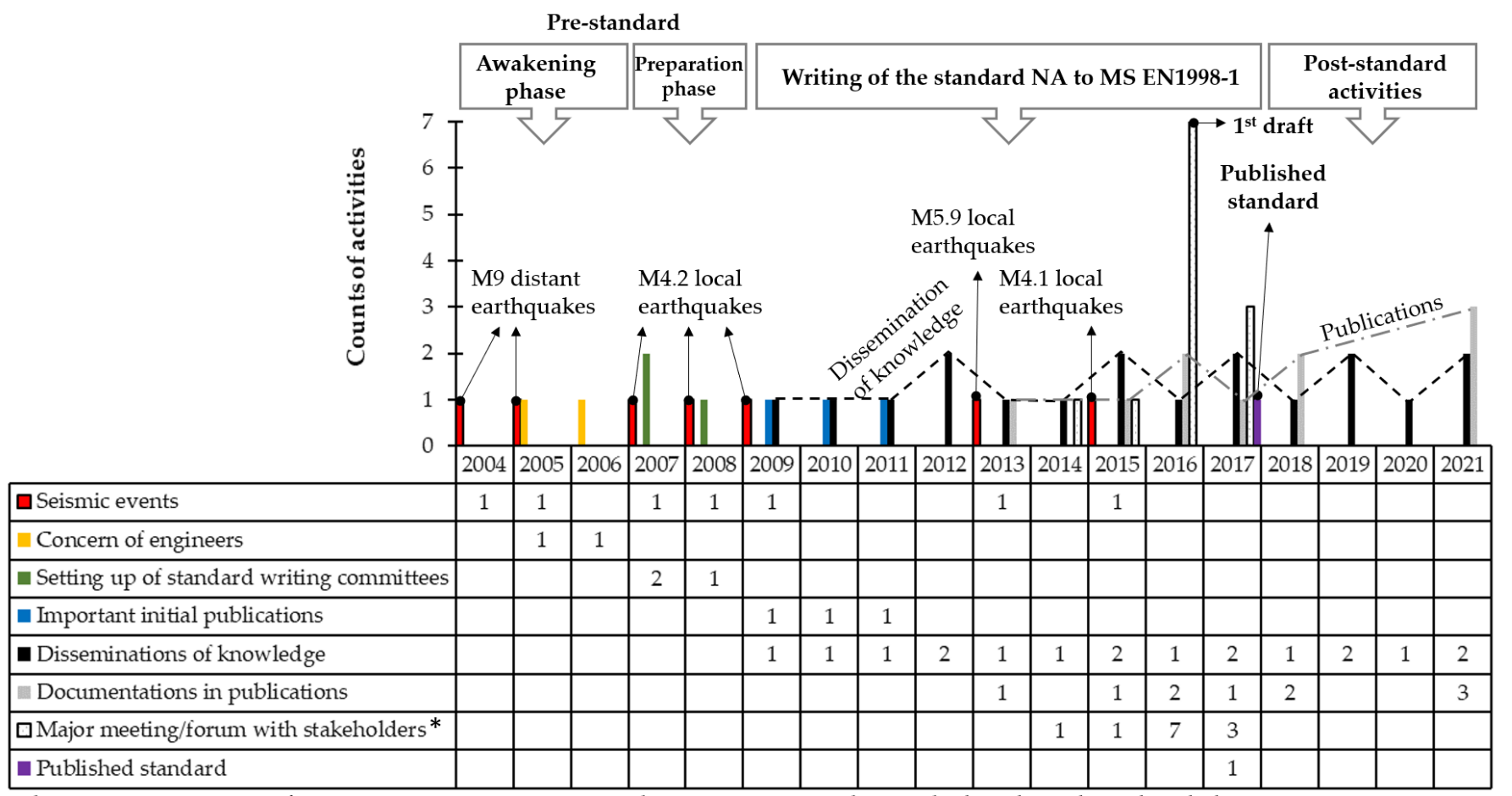

${ }^{*}$ These are major meetings/forums. Frequent communications between group members took place throughout the whole process.

Figure 1. The roadmap of the drafting of the Malaysia NA of EC8 [1,2].

\subsection{Pre-Standard: The Awakening and Preparation Phases (2004-2009)}

Moderate size seismic events of magnitude 5 to 6 (M5-M6) occurring in Malaysia in the 1900s had been documented. The affected areas were mostly not so densely populated areas in Sabah (e.g., M5.3 in 1966 near Ranau, M6.2 and M5.7 in 1976 and 1994, respectively, near Lahad Datu). These early events had not drawn significant attention because of the sparse population in the affected areas where there were very few engineered building structures of significance. Memories of those events had faded away over time. However, there were also a few notable events, such as the Aceh M9.1-9.3 and Nias M8.6 megathrust subduction (interplate) earthquakes, which occurred offshore of Sumatra in 2004 and 2005, respectively. The epicentres of these earthquakes were at a far distance of about $600 \mathrm{~km}$ from Peninsular Malaysia, but many residing along the west coast of the Peninsular felt the shaking. Given the concern raised by the public, the Civil and Structural Engineering Technical Division of the Institution of Engineers Malaysia (IEM) took the initiative to write a position paper which was published in 2008 [4]. The position paper raised concern over the lack of preparedness of the Malaysian engineering industry in seismic design. Some short- and long-term measures to address the potential risks are recommended.

In 2008, IEM was appointed by the Department of Standards Malaysia as the standardswriting organisation for the Malaysia NA to EC8. Working Group 1 (WG1) was formed un- 
der a Technical Committee (TC) on Earthquakes to study the seismic hazard in Malaysia [5]. Whilst the initial focus was on distant interplate earthquakes generated from offshore sources, attention has also been drawn onto local intraplate earthquake events which had been recorded within the peninsular. Such events include the M4.2 earthquake tremor which occurred in 2007-2009 at Bukit Tinggi, which was about $30 \mathrm{~km}$ away from Kuala Lumpur, the capital city of Malaysia. The TC adopted the approach of addressing seismic risks holistically, and both local intraplate earthquakes and distant interplate earthquakes deserved an equal amount of attention.

\subsection{The Standard-Writing Phase (2009-2017)}

WG1 members acknowledged the challenges of dealing with seismic risks in a low-tomoderate seismicity region where representative locally recorded earthquake data were so lacking that undertaking seismic hazard assessments in a conventional manner would not be delivering any meaningful predictions. Hence, international experts in the low-tomoderate seismicity regions (the second and last authors of this paper) were invited to join the special study group under WG1 in June 2010. The first author was the candidate selected by WG1, trained under an apprenticeship program in grooming local talents for seismic engineering [5]. At a time when there was no existing ground motion model that could be applied to predict subduction earthquakes of mega magnitude (of the order of M9), the study put the focus on three key publications for the prediction of ground motions generated by distant interplate earthquakes [6-8]. Publications cited in the review laid the foundation of the seismic hazard study for Malaysia.

The main development activity was the drafting of the Malaysia NA to EC8 and was paralleled by sourcing input from international experts in the field, as well as working alongside local authorities and influential groups to resolve differences and to disseminate knowledge to local practising professionals through workshops and publications. All these knowledge dissemination activities have been conducted on a regular basis since 2009 , long before the first draft of the national annex was presented for the first round of public comments in 2016 [9]. The standard-writing activities became most intensive in 2016. Around that time, the authors and co-workers travelled to different parts of Malaysia for various meetings, forums and discussions with stakeholders. These activities lasted until the standard was officially published in 2017 [2].

\subsection{Post-Standard Phase (2017 to Current)}

Standard writing is in itself a time-consuming activity. In addition, related work may be prolonged even after the standard is published as it is a natural continuation of obligations of the code drafters. In the case of the Malaysia NA to EC8, substantial knowledge dissemination activities are warranted to ensure that the intention of the standard is well understood by practising engineers. Hence, the authors (together with other local and international team members) have relentlessly dedicated themselves to achieve the goal of the standard following its release in 2017. A notable milestone was the setting up of a public access website (quakeadvice.org, last assessed on 28 October 2021) with free online lectures and software, which is aimed at educating engineers and guiding them into making proper use of the newly launched standard in a low-to-moderate seismicity region [10].

\section{Technical Challenges Faced during the Drafting of the Standard}

During the course of drafting the National Annex, the authors managed to gain highly valuable experiences, which are elaborated in this section. Four main technical challenges were encountered when implementing the EC8 framework into Malaysia. The first challenge was over the prediction of seismic hazards when representative data required for input into a probabilistic seismic hazard assessment (PSHA) were lacking. The second challenge was to do with the need to modify the outdated EC8 site classification scheme, which in its current form could poorly represent the conditions of the site in an earthquake. 
The third challenge was to deal with EC8 mandating Ductility Class Medium (DCM) detailing in localities where the predicted level of seismic hazard exceeds a certain threshold. The fourth challenge was to deal with the requirement of EC8 to involve dynamic analysis of the majority of building structures when most engineers were not familiar with the requisite software. Each of these challenges, along with recommendations on how to best handle them, will be discussed in detail below under separate sub-headings.

\subsection{Challenge 1: The Uncontrolled Use of Probabilistic Seismic Hazard Assessment (PSHA) Methodology}

PSHA is a widely adopted seismic hazard modelling technique introduced in almost every textbook on earthquake engineering and seismic risk modelling [11]. The modelling methodology is perceived by many as being unbiased and scientific. When PSHA was first developed, it was intended for use in areas where data were abundant. In stable areas away from tectonic plate boundaries (i.e., intraplate regions), instrumented data are usually by far too inadequate to inform the spatial and temporal distribution of seismic activities. The use of aerial surveys to identify the location of active fault sources can be problematic because of the existence of blind faults (the location of which has been blurred by erosion or masked by sedimentary deposits). Seismic sources are usually represented as areal sources and are based on mapping the position of the epicentre of historical earthquakes. However, guidance is lacking on how to delineate the boundary of an areal source. Amid a lack of information and guidance, much can be left to the discretion of the operator of PSHA in addressing the unknowns. Thus, predictions derived from the same set of data can be non-unique. In an area where data are sparse, the modelled level of hazard in the vicinity of a historical earthquake would always be higher than before. This implied phenomenon of thePSHA as a predictive tool is an irony given that predictions so derived from it cannot be repeated over time [12]. The standard practice to resolve differences in opinion is to employ the so-called logic tree (decision making by "show of hands") procedure. This is another irony of the PSHA as a scientific procedure, as the outcome of the modelling is susceptible to influence by personal, commercial and political interests.

In EC8, the no collapse performance objective is based upon a recommended design return period (RP) of 475 years, which corresponds to a probability of exceedance of $10 \%$ in a 50-year design lifespan of a building. The concept of the Maximum Considered Earthquake (MCE) has not been incorporated into its underlying design philosophy, given that the code was drafted in the mid-1990s, at which time it was still the norm to design the majority of building structures for a return period of up to 500 years. Seismic design provisions around the world have evolved since that time. Notably, at present, there is a general consensus amongst earthquake engineers that an MCE event for normal buildings should have a RP of around 2500 years, which is consistent with a probability of exceedance of $2 \%$ in 50 years [13]. Importantly, structural designers operating in low seismicity regions are cautioned, herein, that the amount of increase in the ground motion intensity (corresponding to an increase in the RP from 500 to 2500 years) can exceed the default factor of 1.5 by a wide margin. A factor varying between 2.4 and 5 is predicted for intraplate earthquakes, as shown in Figure 2 [14-16]. As a result, designing a building to the no collapse performance limit state for a RP of 500 years would not in itself be able to offer the building adequate protection from the near-collapse limit state in an MCE. The trend of moving away from the conventional practice of designing to a return period of 500 years was initiated by the influential FEMA450 document [17] to guide the design of new buildings in the United States. The design seismic action was recommended based on an MCE of 2500 years scaled down by a factor of two thirds (reciprocal of 1.5). This scaling factor can be interpreted as the margin between the limit state of no collapse, and collapse prevention, in order that code-compliant buildings can always be assured of their ability not to collapse in a very rare earthquake event [18]. 


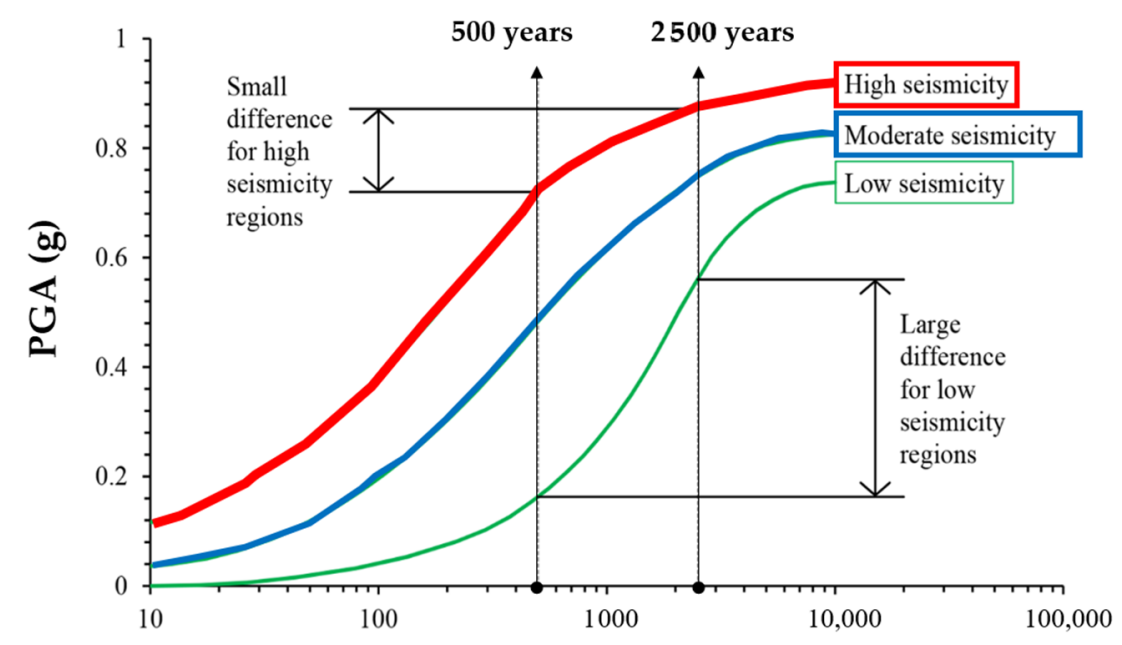

Average return period (years)

Figure 2. PGA-return period correlation with reference to low-, moderate-, and high-seismicity regions [14].

On recommendations made by WG1 in the draft Malaysia NA to EC8 for public comments [9], a minimum level of the reference peak ground acceleration (PGA) on rock $\left(a_{\mathrm{g} R}\right)$ of $0.07 \mathrm{~g}$ was considered to be specified for Peninsular Malaysia and Sarawak and $0.12 \mathrm{~g}$ for most of Sabah. The recommended minimum hazard requirements can be justified by referring to results from PSHA, assuming a uniform spatial distribution of seismic activities and observations on the frequency of occurrence of $M>5$ earthquake events over an extensive area [19]. The $a_{\mathrm{g} R}$ value of $0.07 \mathrm{~g}$ and $0.12 \mathrm{~g}$, as quoted above for a notional return period of 500 years, was two-thirds of the values $(0.10 \mathrm{~g}$ and $0.18 \mathrm{~g}$, respectively), corresponding to a return period of 2500 years, i.e., MCE [20]. The modelling concept as described is likened to that of background seismicity (which is a well-established concept). However, background seismicity models that have been employed in the past for PSHA did not prevent the value of $a_{\mathrm{g} R}$ to go as low as $0.03 \mathrm{~g}$ for a design return period of 500 years.

The requirement of a minimum seismic hazard design factor $(Z$, known as the effective PGA) of 0.08 for a return period of 500 years was implemented in the 2018 revision to the Australian Standard for seismic actions [21]. Thus, in most parts of Australia $Z=0.08$ is specified in the new seismic hazard map, superseding an old model derived originally from conventional PSHA (based on information from documented historical seismic activities). In contrast to the new stipulation, the value of $Z$ in the old map could be as low as 0.03 for areas where no historical activities had been recorded within the period of seismic activity observation. However, unlike the Australian Standard [21], recommendations in the draft Malaysia NA [9] for imposing a minimum seismic loading of $0.07 \mathrm{~g}$ and $0.12 \mathrm{~g}$ to different parts of Malaysia have not been taken up by the enacted version of the Malaysia NA to EC8 [2], which was completed through a decision process based on voting. One of the consequences of the decision is that an unacceptably low $a_{\mathrm{g} R}$ value of $0.04 \mathrm{~g}$ has been stipulated for Kota Kinabalu (the capital city of Sabah), which was only some $50 \mathrm{~km}$ from the epicentre of the M5.9 Ranau earthquake of 2015 (see Figure 3). In addition, given that the modelling has not been subject to any independent audit by a third party, the modeller did not have to abide by any rules nor any form of control. A small interval of $0.01 \mathrm{~g}$ PGA contour was created (as shown in Figure 3) even when such a high-resolution seismic hazard map cannot be justified (given that seismic data has only been recorded from one earthquake event). 


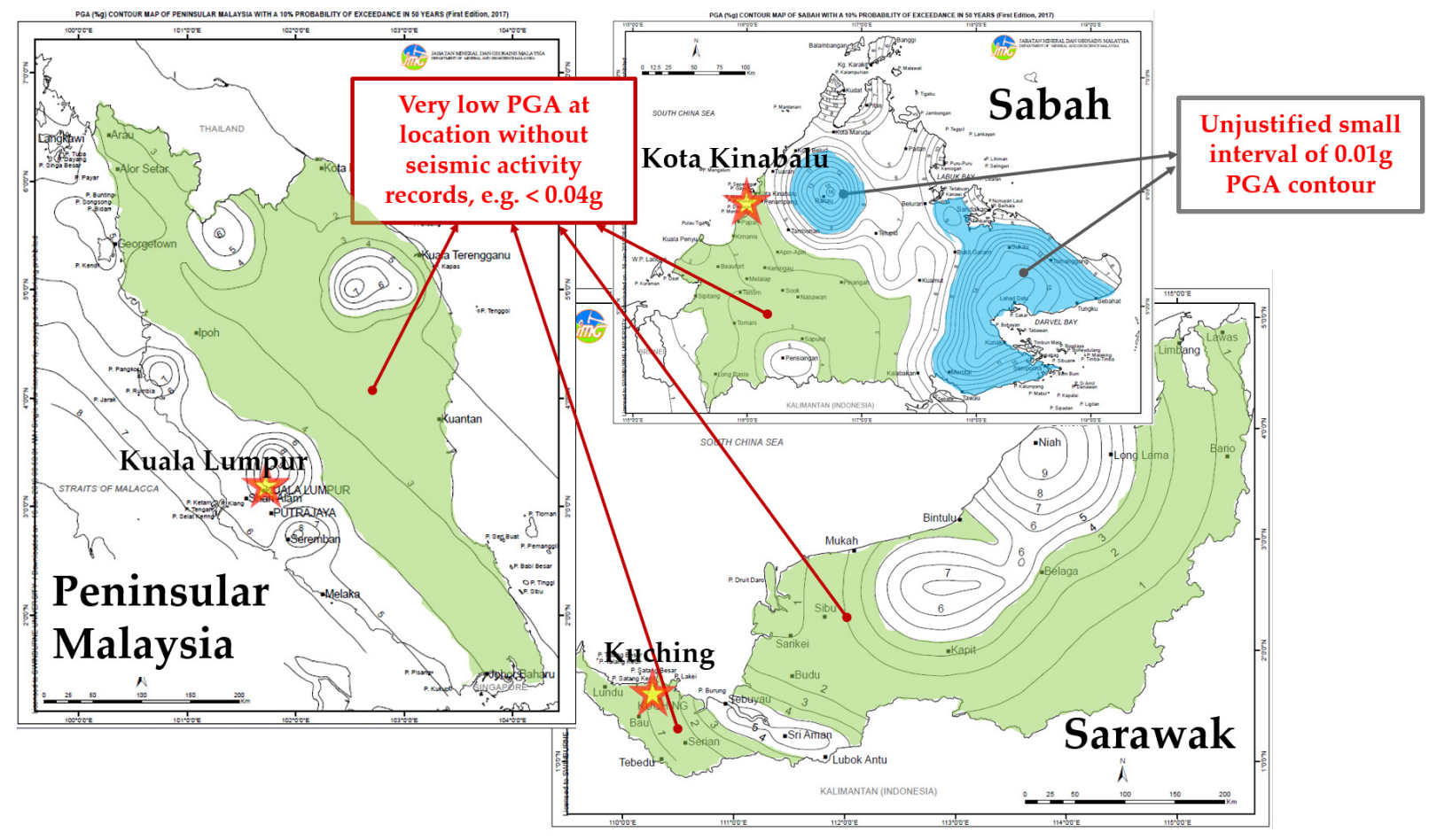

Figure 3. Challenge 1: The uncontrolled use of PSHA methodology in the enacted version of the Malaysia NA to EC8 [2].

The authors pledge all major codes of practice, including EC8, to require seismic hazard maps to be subject to proper auditing and to impose adequate minimum design requirements so that maps such as that shown in Figure 3 do not become part of a legal document for safeguarding the public. The authors recommended adopting a more robust model such as the one depicted in Figure 4. Although the recommended PGA values were originally $0.12 \mathrm{~g}$ for most of Sabah, the stipulated level of hazard has been harmonised to $0.11 \mathrm{~g}$ to have a smooth interval of $0.04 \mathrm{~g}$ across the country (i.e., minimum level of $0.07 \mathrm{~g}$, intermediate level of $0.11 \mathrm{~g}$ and the highest level of $0.15 \mathrm{~g}$ ).

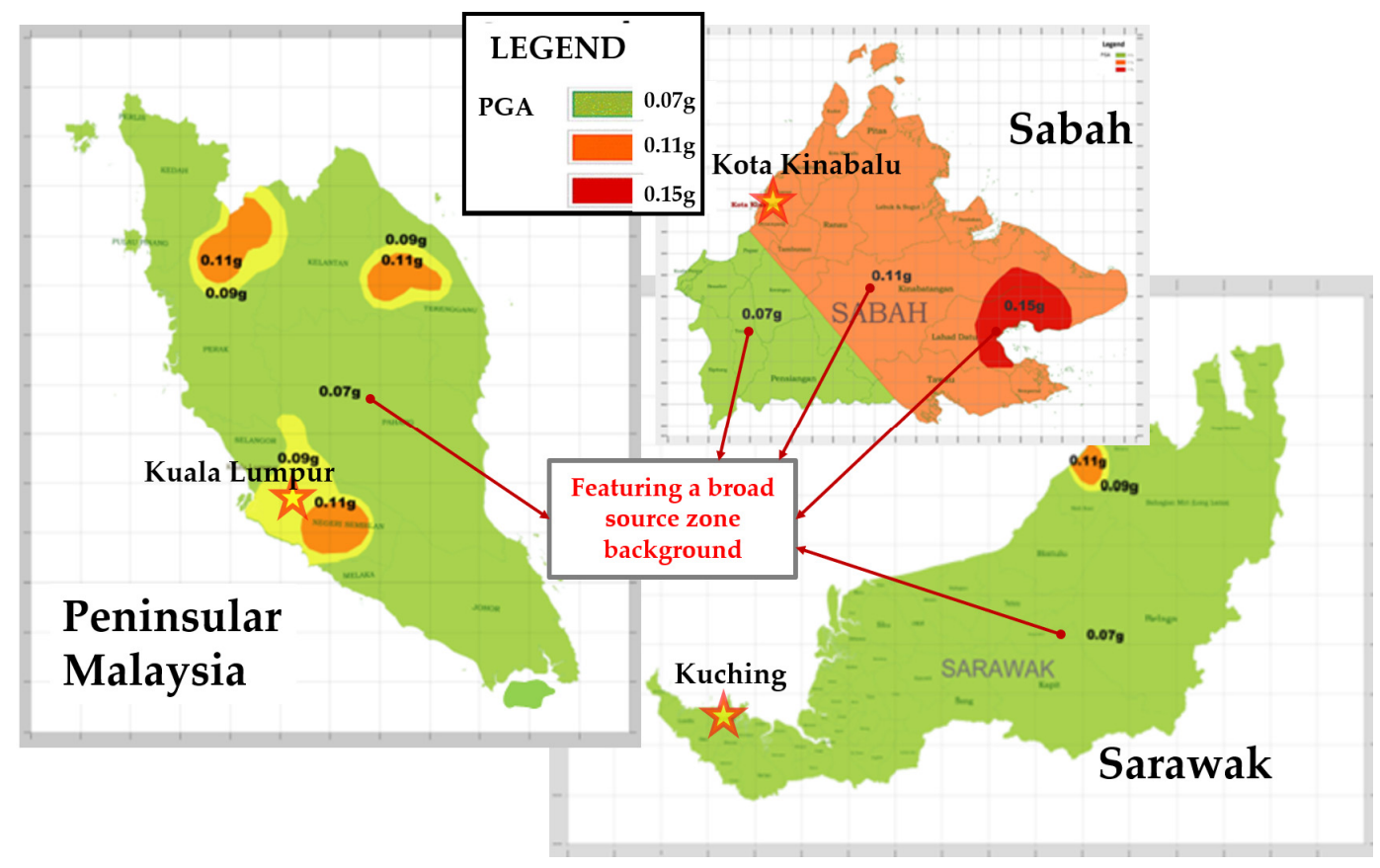

Figure 4. Proposed seismic hazard maps that circumvent Challenge 1. 


\subsection{Challenge 2: The Incomplete EC8 Site Classification Scheme}

In EC8, a site can be classified into a few pre-defined site classes. Site effects are commonly related to a reference site class, i.e., ground type A for rock sites. The inability of this site classification scheme in EC8 to adequately address deep site geology is a matter of concern (see Figure 5). The potential occurrence of resonance can be particularly acute in buildings of limited ductility and more so on deep soil sites. The next edition of EC8 is to be revised to the form with site natural period parameterisation proposed in numerous publications by Pitilakis et al. [22-24]. The basis and justification for incorporating the site natural period as a parameter in the classification scheme and the effects of site resonance in the site amplification factor can be found in earlier studies conducted globally [25-28].

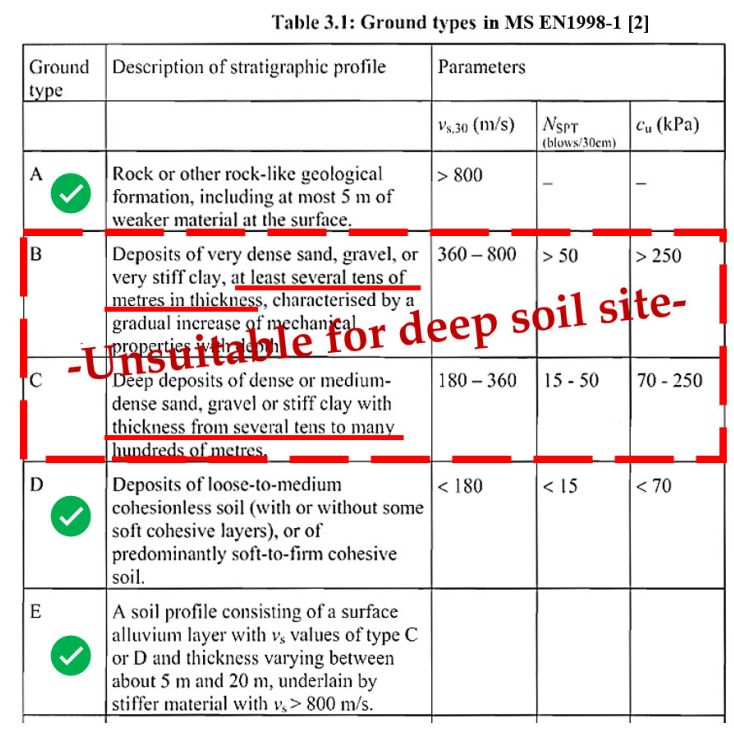

(a)

\section{Suitable ground types in EC8 not considering deep soil site (stiff soil site)}

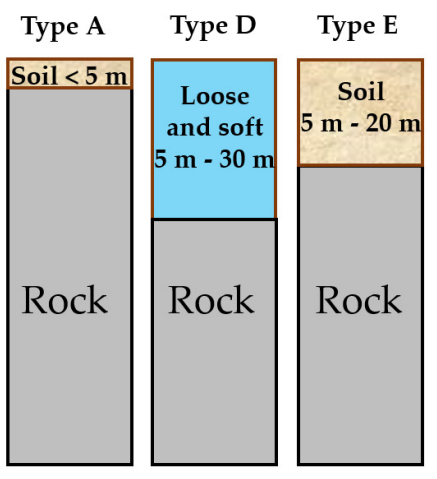

(b)
Unsuitable ground types in EC8 for deep soil site (flexible soil site)

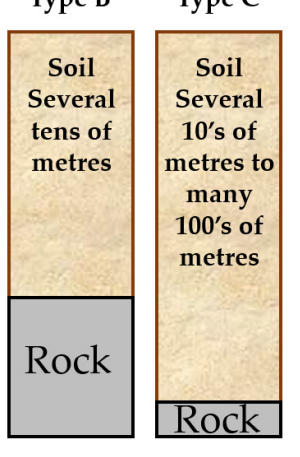

(c)

Figure 5. Challenge 2: The incomplete EC8 site classification scheme. (a) Table 3.1 in MS EN19981-1 [2]. (b) Suitable ground types. (c) Unsuitable ground types.

A site classification scheme which incorporates the site natural period as a parameter was clearly much preferred to the then existing classification scheme of EC 8 and was considered as the next generation classification scheme [22]. However, the transition to the new scheme had not occurred officially at the time when the Malaysian NA to EC8 [2] was drafted. It was decided that the NA adopted the (atypical) approach of having a dual classification scheme. The two schemes are, namely, Model A and Model B. This was purely a pragmatic decision to address political issues in the regulatory process. Model A can be used for shallow soil sites covered by soil sediments of thickness $H_{\mathrm{S}}$ not exceeding $30 \mathrm{~m}$ (Figure $5 \mathrm{~b}$ ), whereas Model B is mandatory for deep soil sites exceeding $30 \mathrm{~m}$ (Figure 6). The response spectrum associated with Model A was not stipulated by the main body of EC 8 but was derived from analyses made by local investigators and was without justifications that have not been published in an international archival source. By contrast, Model B has a theoretical basis validated by site response analyses and field data from the 1994 Northridge earthquake [27,29-31]. As descriptions for the same ground type in the two classification models are totally different, code users can easily be confused. In comparison between the two models, Model B provides more accurate predictions of the real behaviour of a soil column in an earthquake. Model B is free of limitations in relation to the depth of the soil sediments, i.e., it can be applicable to soil sediments of any depth. Model B is recommended by the authors because of the deficiencies of Model A in covering for deep geology and more so where there is a distinct soil-rock interface. 


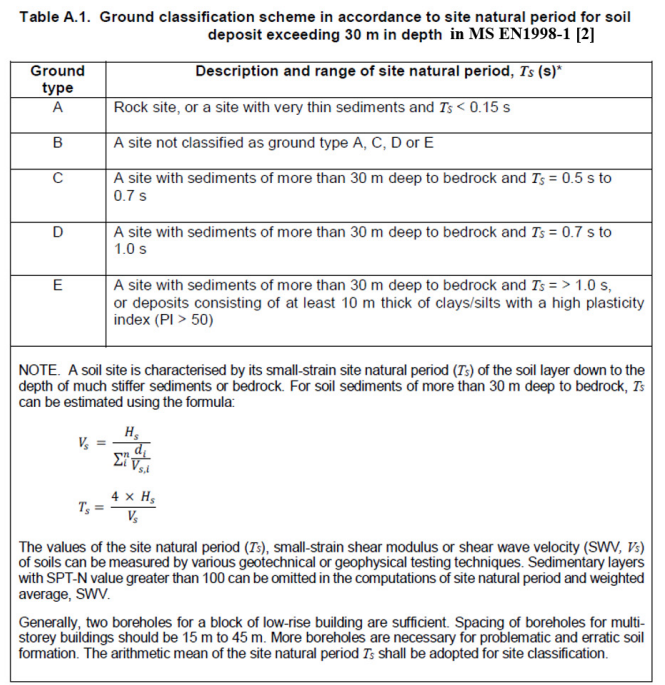

(a)

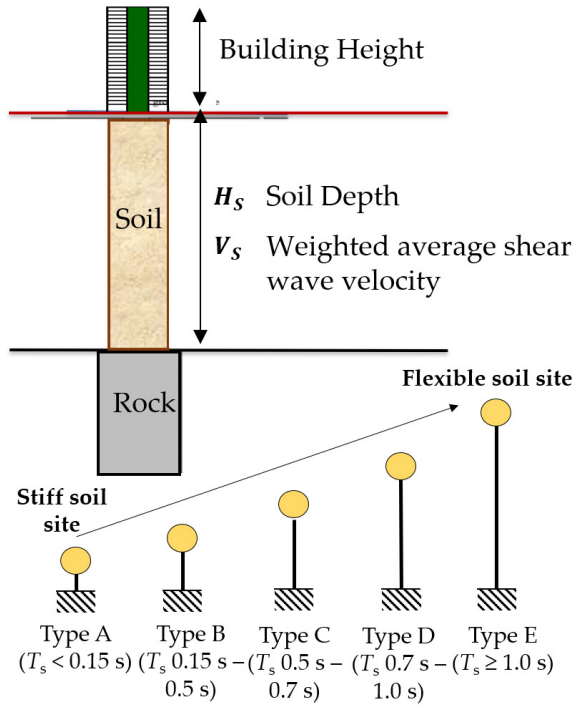

(b)

Figure 6. Solution to circumvent Challenge 2 with a new site classification scheme. (a) Definition for Model B from the Malaysia NA to EC8 [2]. (b) Analogy of stiff soil and flexible soil sites according to single-degree-of-freedom lumped mass oscillators.

With Model B, the rock-soil amplification ratio has its maximum value occurring at the site natural period $\left(T_{S}\right)$. Figure 6a shows the five ground types as defined by the range of values of $T_{S}$. Apart from ground type A, which refers to rock sites (or very stiff soil sites), all other ground types refer to soil sites. Ground types $\mathrm{A}$ to $\mathrm{E}$ correspond to $T_{S}$ values ranging from low to high, and with transitions at $T_{S}=0.15 \mathrm{~s}, 0.5 \mathrm{~s}, 0.7 \mathrm{~s}$ and $1.0 \mathrm{~s}$, which can be viewed in analogy with a series of single-degree-of-freedom lumped mass oscillators model as shown by Figure $6 \mathrm{~b}$. The value of $T_{S}$ is based on the conditions of small shear strains in the soil. The shear wave velocity $\left(\mathrm{SWV}, V_{S}\right)$ of soils can therefore be estimated based on geophysical or geotechnical measurements involving the use of Equation (1). The value of $T_{S}$ can be taken as four times the travel time taken by seismic waves traversing the sedimentary layers overlying bedrock:

$$
T_{s}=4 \times \sum_{i=1}^{n} \frac{d_{i}}{V_{i}}=\frac{4 H_{s}}{V_{s}},
$$

where $d_{i}$ is the thickness, $V_{\mathrm{i}}$ is the initial SWV of the $i$-th soil layer, $H_{S}$ is the total thickness of the soil layers and $V_{S}$ is the weighted average SWV. Sedimentary layers with SPT-N values greater than 100 can be omitted in the computation of the site natural period and weighted average SWV. The authors proposed effective ways to choose the empirical equations to convert SPT-N to SWV [32] based on recommendations presented in a PEER report [33].

Model B has been reviewed and endorsed by Professor Kyriazis Pitilakis-current President (2018-2022) of the European Association of Earthquake Engineering (EAEE), who has been the Coordinator of the EAEE Working Group 6 on Geotechnical Earthquake Engineering, leading the future revision to EC8 concerning geotechnical matters [34].

In summary, site classification Model B was introduced to address the concern that the site response behaviour of deep soil sediments where the total thickness of the soil sedimentary layers overlying bedrock exceeds $30 \mathrm{~m}$. The key feature of this classification model is the incorporation of the site natural period as the key modelling parameter. Model $B$ is therefore generic in nature and is found on sound theoretical principles to emulate real response behaviour of soil sediments of different depths.

In a case study of a normal stiff soil site of $30 \mathrm{~m}$ depth (see Figure 7a) and a deep soil site of $58 \mathrm{~m}$ (see Figure $7 \mathrm{~b}$ ), the soil sediments had a common weighted average shear 
wave velocity of $222 \mathrm{~m} / \mathrm{s}$. The soil response spectra in both cases as obtained from the 1D site response analyses using STRATA [35] are presented in the format of AccelerationDisplacement Response Spectrum (ADRS) diagrams. It is shown that the proposed design response spectrum (DS) models adopted as Model B in the Malaysia NA to EC8 match the site response analysis results very well [31].

Normal depth soil site

\begin{tabular}{|c|c|c|}
\hline$H_{S}(\mathrm{~m})$ & $V_{S}(\mathrm{~m} / \mathrm{s})$ & $T_{S}(\mathrm{~s})$ \\
\hline 30 & 222 & $\mathbf{0 . 5 4}$ \\
\hline
\end{tabular}

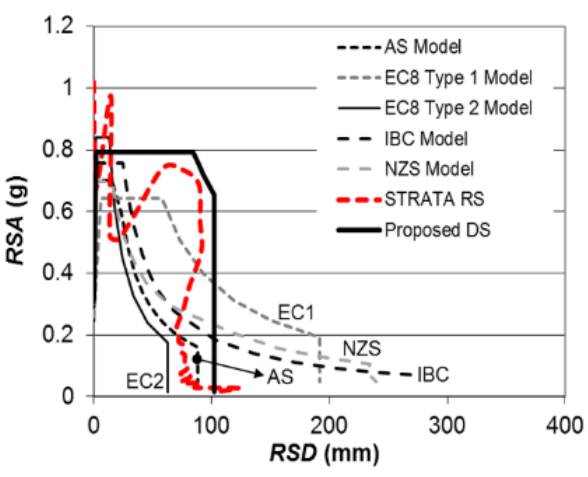

(a)
Deep soil site

\begin{tabular}{|c|c|c|}
\hline$H_{S}(\mathrm{~m})$ & $V_{S}(\mathrm{~m} / \mathrm{s})$ & $T_{S}(\mathrm{~s})$ \\
\hline 58 & 222 & 1.0 \\
\hline
\end{tabular}

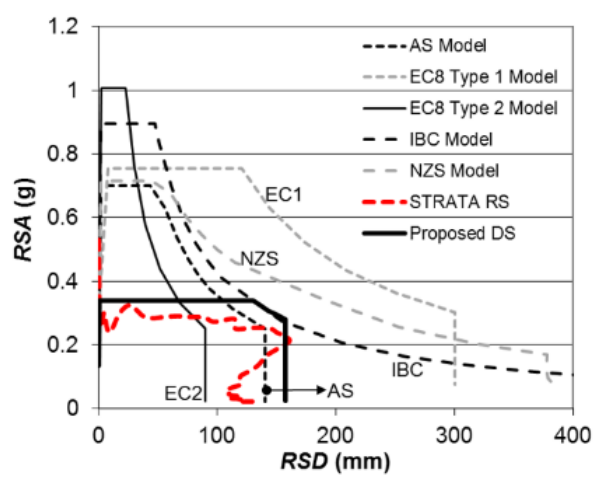

(b)

Figure 7. Proposed design response spectrum (DS) model based on Model B in the Malaysia NA to EC8 for (a) a normal $30 \mathrm{~m}$ depth soil site with $T_{S}=0.54 \mathrm{~s}$ and (b) a flexible deep soil site having the same weighted average shear wave velocity with $T_{S}=1 \mathrm{~s}$ [31]. The proposed model matches site response analysis results from STRATA [35].

\subsection{Challenge 3: EC8 Mandated the Use of DCM Ductile Detailing for Higher Seismic Hazard Level}

The third challenge was that EC8 had mandated Ductility Class Medium (DCM) detailing, which was about designing the structure to develop an inelastic response mechanism to dissipate energy in seismic conditions. This design approach is common in areas that are stipulated with a high level of hazard. EC8 recommended a set of pre-defined thresholds for very low, low and high seismic hazard levels as informed by Nationally Determined Parameters (NDPs). Introducing EC8 as an independent document instead of imposing seismic design provisions into various material standards was to make it easier for countries with a very low level of seismic hazard to opt out of adopting EC8 at all [36]. However, there has not been much guidance for regulators in low-to-moderate seismicity regions on how best to optimise the design and detailing requirements of building structures.

Figure 8 a shows the concept of a force-based seismic design approach in which a behaviour factor ( $q$-factor in EC8 [1]), or a similar set of factors, is introduced to lower the design strength of the seismic action whilst allowing the structure to experience post-elastic deformation in a ductile manner; the higher the level of ductility and/or overstrength, the higher the $q$-factor. Figure $8 \mathrm{~b}$ shows the range of $q$-factor values recommended in EC8 according to ductility classes. Areas where the value of the design ground acceleration on rock $\left(a_{\mathrm{g}}\right.$, being the product of $a_{\mathrm{gR}}$ with an importance factor, $\left.\gamma_{\mathrm{I}}\right)$ is lower than $0.08 \mathrm{~g}$, or where $a_{\mathrm{g}} S$ is lower than $0.10 \mathrm{~g}$ (where $S$ is the soil factor), the condition of seismicity is classified as "low". Structures located in these areas can be designed to Ductility Class Low (DCL) in alignment with design compliance with the respective material-specific design standard. For example, structures built of reinforced concrete (RC) are designed to requirements stipulated by Eurocode 2 (EC2) [37], which is without any seismic detailing provisions. In areas where the hazard level is above the "low" threshold (including borderline cases, say $a_{\mathrm{g}}$ is $0.09 \mathrm{~g}$ ), designers are compelled to comply with ductile design 
and detailing practices consistent with requirements in areas of high seismicity. This approach to seismic design may seem logical to some. However, the authors experienced major issues when implementing it in Malaysia.

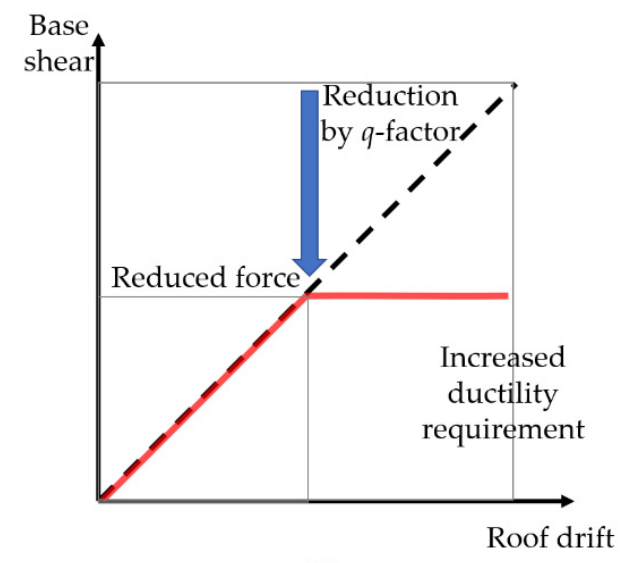

(a)

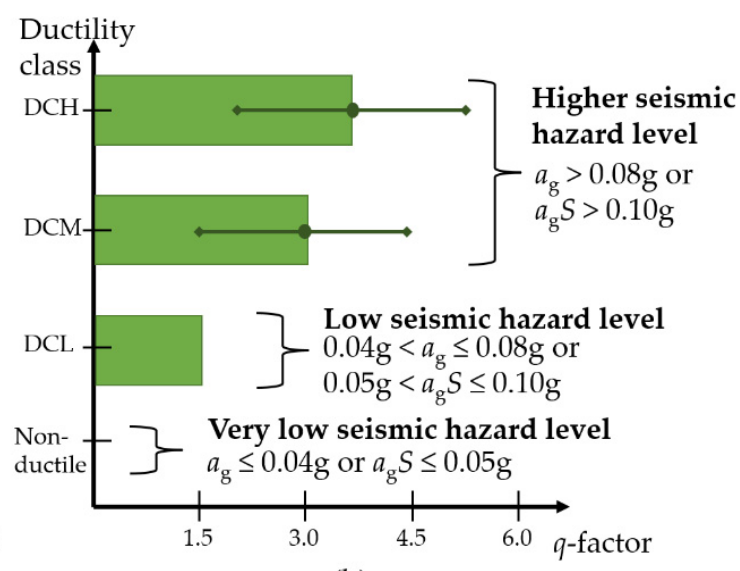

(b)

Figure 8. Challenge 3: The mandated use of DCM at the pre-defined threshold of seismic hazard level (a) the use of $q$-factor to trade-off strength with ductility in force-based methods $(\mathbf{b})$ the pre-defined threshold in EC 8 .

In regions of low-to-moderate seismicity, such as Malaysia, practising engineers typically lack knowledge and experience in incorporating ductility into the design of a structure. The authors faced difficulties communicating the practice of ductile detailing (which was not the only viable way to counter seismic actions [38]) to the Malaysian engineering community in various seminars or events held for knowledge dissemination purposes. Dialogues with local structural design practitioners revealed the sentiment that DCM design should never be made compulsory, given that strength could be traded off with ductility. In the original draft of Malaysia NA to EC8 [9], which was prepared by the authors, building structures should have the option of adopting DCL irrespective of its location. This regulatory approach could be accomplished by altering the NDP for the low seismic hazard level so that no structure is compelled to be designed to DCM requirements (noting that DCH is overly complicated [38] and is only suitable for use in high seismic areas).

However, given the lack of justifications from the literature, the recommendations made by the authors in the original draft were challenged by a group of local investigators. As a result, the published Malaysia NA to EC8 [2] does not provide the option of adopting DCL for all building structures. Instead, the NA was to simply go by the recommended seismic hazard thresholds of EC8 when deciding if the design is to adopt DCL or DCM design and detailing. The authors strongly advocate improving current building design practices in low-to-moderate seismicity regions which are proliferated with structures lacking considerations of the performance of the structure in seismic conditions. However, linking the seismic hazard level of an area to ductile design classification is an outdated concept, gives little regard to local practices and is ineffective in ensuring a safe and sustainable built environment. Blindly imposing DCM design requirements would not deliver the desired outcomes.

The published Malaysia NA to EC8 [2] may result in many areas in the country being subjected to DCM design requirements. In anticipation of this challenge to engineering practice, the authors took the proactive initiative to assist practising engineers in coping with DCM design in RC buildings. Looi et al. [39] summarised the steps and developed EC8 DCM tools for rectangular RC columns (see Figure 9 for a snapshot) and RC shear walls (see Figure 10 for a snapshot). Designing RC columns and shear walls to DCM requirements requires determining the ductility demand (Step 1) and the associated con- 
finement requirements (Step 2), which are to be compared against the confinement capacity (Step 3).
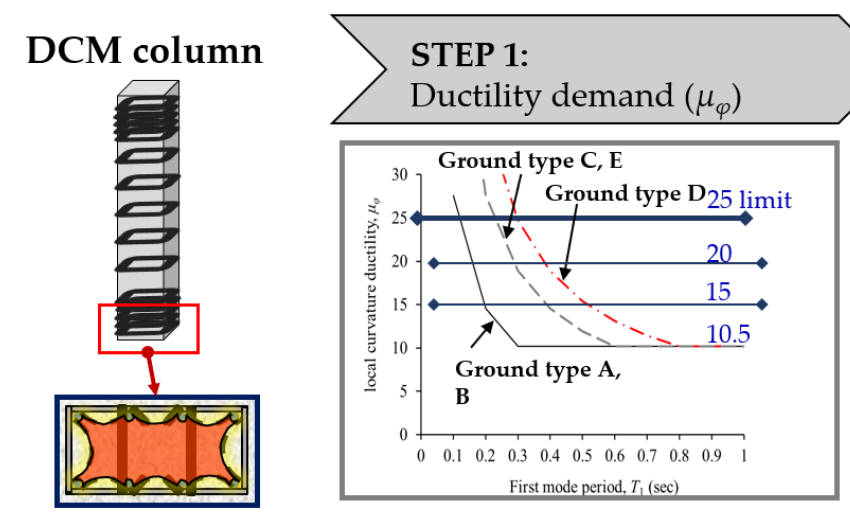

STEP 2:

Confinement_demand $\left(C_{\mathrm{d}}\right)$

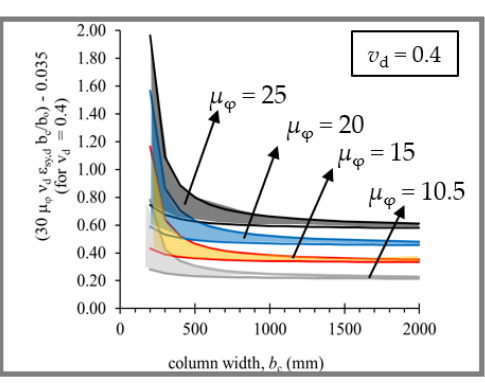

STEP 3: Confinement capacity $\left(C_{c}\right)$
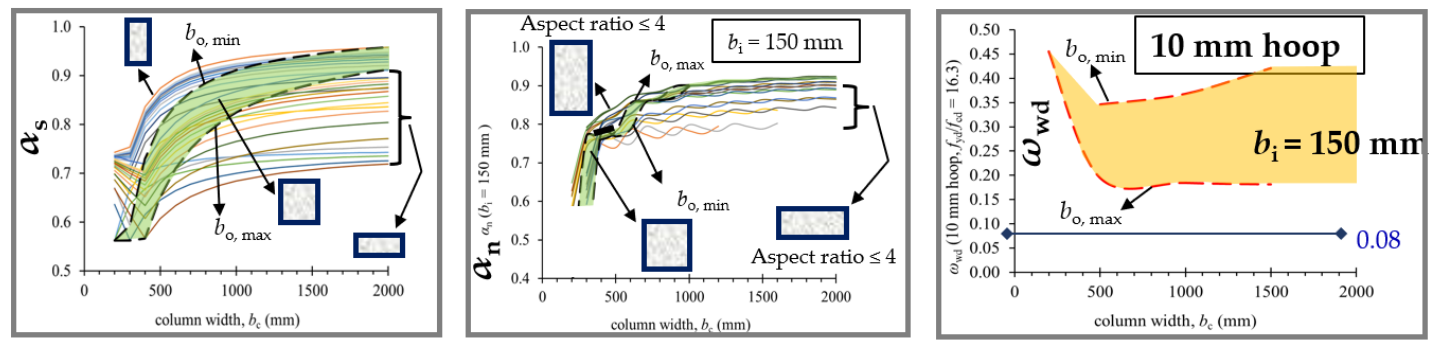

Figure 9. Developed DCM tools for rectangular RC columns to circumvent Challenge 3 [39].

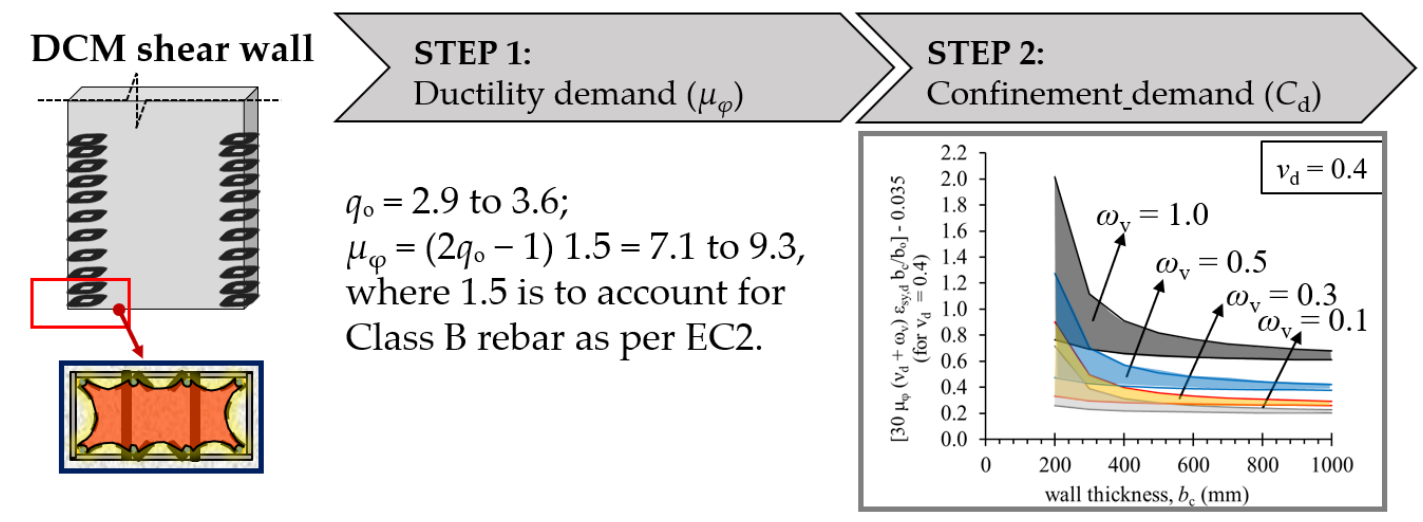

STEP 3: Confinement capacity $\left(C_{\mathrm{c}}\right)$
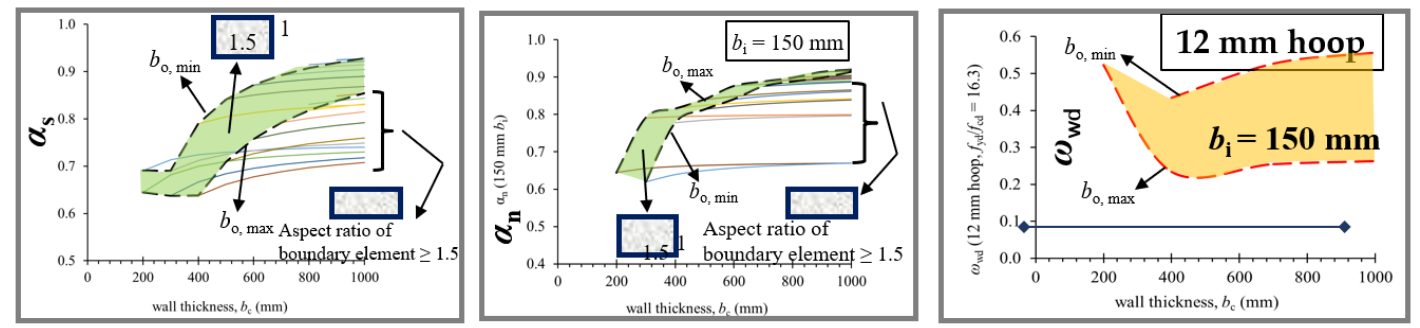

Figure 10. Developed DCM tools for RC shear walls to circumvent Challenge 3 [39]. 
A summary of the design recommendations is listed in Table 1. The length of the boundary elements is either 0.15 times the wall length or 1.5 times the wall thickness, whichever is higher. The rather complex and tedious confinement design procedure is hence circumvented. Interestingly, the presented design solutions are consistent with the draft provisions of the second generation of EC8 [40].

Table 1. Summary of recommendation for simplified DCM for RC buildings.

\begin{tabular}{ccc}
\hline RC Elements & Parameters & Recommended Values \\
\hline \multirow{3}{*}{ Beam } & Depth & $600 \mathrm{~mm}$ \\
& Hoop diameter & $10 \mathrm{~mm}$ \\
& Hoop spacing & $150 \mathrm{~mm}$ \\
& Longitudinal rebar diameter & $20 \mathrm{~mm}$ \\
\hline \multirow{2}{*}{ Rectangular columns } & Size & $500 \mathrm{~mm} \times 500 \mathrm{~mm}$ \\
& Hoop diameter & $12 \mathrm{~mm}$ \\
& Hoop spacing & $150 \mathrm{~mm}$ \\
& Longitudinal rebar diameter & $20 \mathrm{~mm}$ \\
& Longitudinal rebar spacing & $150 \mathrm{~mm}$ \\
& $\alpha_{\mathrm{n}}$ & 0.78 \\
& $\alpha_{\mathrm{s}}$ & 0.73 \\
\hline Shear walls & Thickness & $400 \mathrm{~mm}$ \\
& Boundary length & $600 \mathrm{~mm}{ }^{1}$ \\
& Hoop diameter & $16 \mathrm{~mm}($ or bundled rebars $)$ \\
& Hoop spacing & $150 \mathrm{~mm}$ \\
& Longitudinal rebar diameter & $20 \mathrm{~mm}$ \\
& Longitudinal rebar spacing & $150 \mathrm{~mm}$ \\
& $\alpha_{\mathrm{n}}$ & 0.80 \\
$\alpha_{\mathrm{s}}$ & 0.70 \\
\hline
\end{tabular}

$\overline{1}$ The confined boundary element length has not considered the confined compression zone $x_{\mathrm{u}}$ at ultimate curvature estimated from equilibrium.

EC8 has imposed what is widely perceived as strict and complex rules for RC design and detailing. Preparing a full-fledge DCM based design calculation could be a daunting task to many engineers practicing in low-to-moderate seismicity regions. To circumvent around this challenge to Malaysian engineers, the authors have developed simple deemed-to-comply rules for achieving DCM compliance for the seismic design of $\mathrm{RC}$ beams, columns and shear walls. Meanwhile, it was revealed from past experimental research on RC columns [41,42] and RC shear walls $[43,44]$ that deformability was severely degraded in conditions of high axial compression. Practitioners are urged to control the amount of axial compression on RC members irrespective of confinement provisions for ductility.

\subsection{Challenge 4: EC8 Imposes Modelling of Irregular Buildings for Dynamic Analysis}

EC8 provides a code-based lateral force method to emulate seismic behaviour by applying equivalent static forces to the building. However, this code-stipulated simplified analysis method is subject to stringent pre-qualification criteria which are concerned with vertical and horizontal regularity. Most of the building stocks in Malaysia feature irregularities in planning, such as asymmetrically disposed structural walls around the building, resulting in a significant eccentricity of the centre of rigidity from the centre of mass of the building. This form of irregularities can be compound with other forms of irregularities such as setbacks, discontinued load paths and transfer structures. EC8 prohibits the use of the lateral force method on a building that possesses any of these irregularity features. EC8 stipulates three-dimensional (3D) dynamic analysis (or modal response spectrum analysis) as the default analysis procedure. Executing dynamic analysis in a controlled manner requires expertise and experience in structural dynamics, and such engineering skills can be scarce in a country where seismic design practice has yet 
to be established. This type of challenge in Malaysia is common to other countries of low-to-moderate seismicity. To circumvent the challenge, the authors have devised a simple and yet accurate method of structural analysis (referred herein as the Generalised Force Method, GFM) that can be applied to multi-story buildings featuring horizontal and vertical irregularities. A key feature of GFM is that it does not rely on any code-based empirical formula to predict the natural period of vibration of the structure. The GFM may be applied at three different levels depending on the building (see Figure 11): GFM-1 is suitable for use in the 2D analysis of low-rise buildings; GFM2 has been enhanced to handle taller buildings, as higher mode effects have been taken into account (whilst generalised mode shapes and default modal period ratios are made use of to eliminate the need of modal analysis); and GFM3, which is structured into three tiers (Quick, Refined or Detailed methods), has been enhanced further to handle 3D phenomena [45]. Interested readers are recommended to read into recent publications presenting the GFM [45-47].

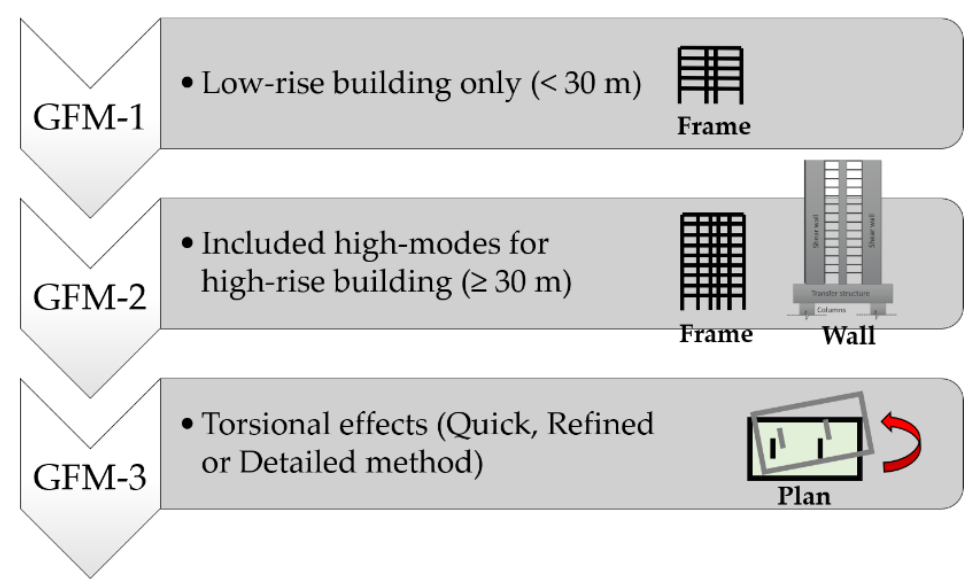

Figure 11. GFM methods to check dynamic analysis results.

The GFM has been demonstrated to provide reliable predictions on the deflection behaviour in buildings, including high-rise buildings and torsion-sensitive buildings (see Figure 12). GFM can be used as a tool to benchmark results generated by the computer in order to exercise control over the use of commercial software in undertaking complex analyses and to enable the design engineers to gain better understanding of the seismic response behaviour of the building.

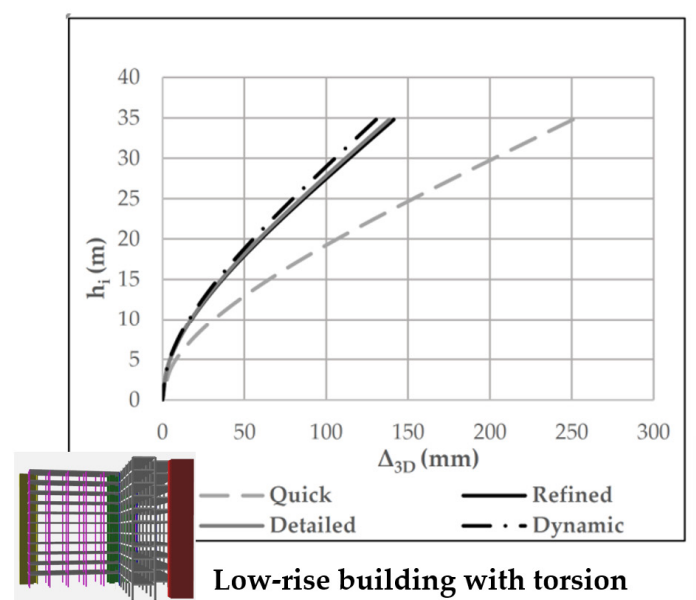

(a)

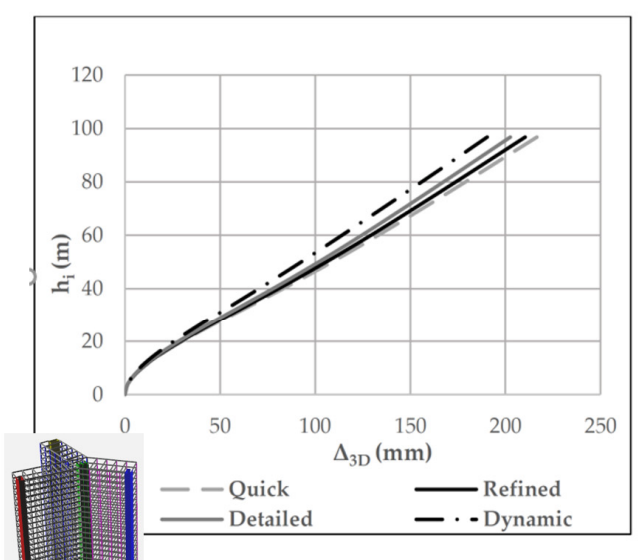

High-rise building with torsion

(b)

Figure 12. Validated examples of displacement profiles using the GFM methods: (a) asymmetrical low-rise building (b) asymmetrical high-rise building. 


\section{Future Outlook of the Second Generation of EC8 and Beyond}

Standard drafting can be very time-consuming and baffled by many challenges. Take EC8 as an example: The first version was published in 2004 following a gestation period of nearly 20 years [48]. Revision to EC8, which is still underway, has been discussed in a few publications [36]. The second generation of EC8 was originally expected to have been concluded around 2020 [48] but had to be postponed to the end of 2021 and, subsequently, postponed further to 2022 (noting that its release is affected by the schedule of releasing a few related codes) [38]. Several key features in the revision as reported in the literature are summarised as follows [36,38,48]:

1. The number of NDPs is reduced by harmonisation, and this requires international consensus among the European member states.

2. The second generation of EC8 aims to improve its clarity by simplifying clauses and removing rules with limited practical utilities (i.e., overly "academic" provisions). For instance, the dependence on ductility classes to the level of seismicity is under review. The conditions of low-to-moderate seismicity areas require special considerations [38]; the number of ductility classes is consolidated from three to two [36,38]; the use of two spectral shapes Type 1 and Type 2 is to be abandoned [38]; the soil classification scheme and the associated site-factor models are to be revised [22-24]; methods of analysis for handling irregularities in buildings are also under review [38].

3. Research findings to fill the voids of knowledge and include introducing new methodologies for handling post-tensioned buildings, flat slab buildings and high-strength concrete.

4. Allow changes to evolve gradually. Engineers who have been trained to operate with the existing version of EC8 should not have much difficulty adapting to the new version. On a separate note, earthquake engineering is a fast-evolving discipline (e.g., the use of conditional mean spectrum [49] and risk-targeted hazard spectra [50] with the considerations of community resilience [51]). Hence, the EAEE has set up a working group entitled 'Future direction for EC8' to oversee the long-term development of EC8 through establishing broad guiding principles that are in alignment with the latest development and to gradually phase out outdated practices which are founded on technologies developed as far back as the 1990s or earlier [52].

\section{Conclusions}

This paper aims to record important milestones achieved by the authors and coworkers, who have been engaged for over a decade in developing the first seismic design standard for Malaysia in the form of a NA to EC8 [1,2]. NDPs were introduced in EC8 to resolve differences where consensus could not be reached amongst the European Commission member states during the drafting of EC8 [36]. Ironically, the authors encountered similar challenges as consensus over the NDP of the nation could not be reached. In addition, four major technical challenges stemming from outdated clauses in EC8 and their lack of fit for use in a low-to-moderate seismic environment were highlighted, discussed, and critiqued. A few key challenges have been brought up for detailed discussions, as summarised below:

1. There was a lack of control in applying the PSHA methodology to areas with a paucity of representative and reliable seismic data. To address this situation, imposing a minimum level of seismic hazard was recommended.

2. Areas typified by limited ductile building construction can be susceptible to soilstructure resonance, and more so on deep soil sites [31]. A conventional site factor model, such as that stipulated in EC8, would not cater for resonance conditions as described. An alternative site classification scheme in which the site natural period is an explicit modelling parameter was introduced.

3. The regulatory approach of mandating DCM ductile detailing requirements following the level of seismic hazard of the area (as shown on the seismic hazard maps) is an outdated practice. The viable option of using strength to trade off for ductility was 
recommended. In addition, a simplified set of code-compliant DCM designs for RC columns and walls has been developed by the authors to circumvent the need to apply the complex design procedures as stipulated by EC8.

4. Amid the proliferation of commercial structural analysis software, EC8 mandates the use of dynamic analysis in the design of the majority of buildings. Dynamic analysis necessitates engineering skills and experiences that are scarce among engineers in Malaysia and other low-to-moderate seismicity regions. GFM methodology was introduced by the authors to exercise control of the use of commercial software avoiding the "black box" syndrome.

The future development of EC8 has been actively discussed in the literature in recent times [38]. Some of the new features are interestingly aligned with recommendations by the authors in relation to the four challenges discussed in this paper. The authors concur with the view that an effective standard should feature stability, simplicity and harmonisation $[36,38,48]$. Hence, it is also hoped that the next generation of EC 8 contains well-defined provisions, free of grey areas and overly constrained clauses. Future developments of regulatory control for seismic design in low-to-moderate seismicity regions need to be approached in context with existing structural design practices in these regions.

Author Contributions: Conceptualisation, D.T.W.L., N.L. and H.-H.T.; methodology, D.T.W.L., N.L. and H.-H.T.; software, D.T.W.L. and H.-H.T.; validation, D.T.W.L. and H.-H.T.; formal analysis, D.T.W.L., N.L. and H.-H.T.; investigation, D.T.W.L., N.L. and H.-H.T.; writing-original draft preparation, D.T.W.L.; writing-review and editing, N.L. and H.-H.T.; visualisation, D.T.W.L. and H.-H.T.; supervision, N.L. and H.-H.T.; project administration, D.T.W.L., N.L. and H.-H.T. All authors have read and agreed to the published version of the manuscript.

Funding: Part of this research and standard drafting work in the maintenance of the www.quakeadvice. org website (last accessed on 28 October 2021) for knowledge dissemination was funded by Swinburne University of Technology (Sarawak Campus) with a Learning and Teaching Grant, grant number 2-2283.

Institutional Review Board Statement: Not applicable.

Informed Consent Statement: Not applicable.

Acknowledgments: The authors acknowledge the supports given by the Institution of Engineers Malaysia (IEM) over the years in drafting the Malaysia NA to EC8. The authors are indebted to the late MC Hee, for bringing the authors together in this journey of standard writing. The authors are also grateful for the support given by John Wilson, Elisa Lumantarna, Scott Menegon, EP Lim, Prashidha Khatiwada and Yiwei Hu in related research activities.

Conflicts of Interest: The authors declare no conflict of interest.

\section{Appendix A}

Table A1. The details of the chronological activities from 2004 to current year 2021 in the writing of the Malaysia NA to EC8.

\begin{tabular}{|c|c|c|c|c|}
\hline No. & Events & Location & Year & Remarks \\
\hline 1 & Sumatran subduction M9 earthquake & Acheh, Indonesia & 2004 & Seismic event (1) \\
\hline 2 & Sumatran subduction M8.6 earthquake & Nias, Indonesia & 2005 & Seismic event (2) \\
\hline 3 & $\begin{array}{l}\text { IEM Civil and Structural Technical Division's } \\
\text { position documents }\end{array}$ & Kuala Lumpur & $2005-2006$ & $\begin{array}{l}\text { Concern of engineers in } \\
\text { Malaysia }\end{array}$ \\
\hline 4 & Sumatran subduction M8.4 earthquake & Bengkulu, Indonesia & 2007 & Seismic event (3) \\
\hline 5 & $\begin{array}{l}\text { IEM appointed by Department of Standards } \\
\text { Malaysia to be the Standards Writing } \\
\text { Organisation (SWO) for NA to EC } 8 \text {. }\end{array}$ & Kuala Lumpur & 2007 & $\begin{array}{l}\text { Initiation of standard } \\
\text { writing }\end{array}$ \\
\hline 6 & $\begin{array}{l}\text { IEM set up a Technical Committee (TC) on } \\
\text { Earthquakes and established Working Group } 1 \\
\text { (WG1) }\end{array}$ & Kuala Lumpur & 2008 & $\begin{array}{l}\text { Setting up TC and WG } \\
\text { for standard writing }\end{array}$ \\
\hline
\end{tabular}


Table A1. Cont.

\begin{tabular}{|c|c|c|c|c|}
\hline No. & Events & Location & Year & Remarks \\
\hline 7 & Local M4.2 seismic activities detected & Bukit Tinggi, Selangor & 2007-2009 & Seismic event (4) \\
\hline 8 & $\begin{array}{l}\text { A journal paper "Seismic load estimates of } \\
\text { distant subduction earthquakes affecting } \\
\text { Singapore" in Engineering Structures [6] }\end{array}$ & - & 2009 & $\begin{array}{l}\text { Important publication } \\
(1)\end{array}$ \\
\hline 9 & $\begin{array}{l}\text { Two-Day Course on Earthquake Resistant Design } \\
\text { and Analysis of Buildings and Structures }\end{array}$ & Kuala Lumpur & 2009 & $\begin{array}{l}\text { Dissemination of } \\
\text { knowledge }(1)\end{array}$ \\
\hline 10 & $\begin{array}{c}\text { A journal paper "Ground-motion attenuation } \\
\text { relationship for the Sumatran megathrust } \\
\text { earthquakes" in Earthquake Engineering and } \\
\text { Structural Dynamics [7] }\end{array}$ & - & 2010 & $\begin{array}{l}\text { Important publication } \\
(2)\end{array}$ \\
\hline 11 & $\begin{array}{l}\text { Symposium on Earthquake Ground Motions and } \\
\text { Responses of RC Buildings }\end{array}$ & Kuala Lumpur & 2010 & $\begin{array}{l}\text { Dissemination of } \\
\text { knowledge (2) }\end{array}$ \\
\hline 12 & $\begin{array}{l}\text { Two-Day Course on Analysis and Design to EC8 } \\
\text { Demystified }\end{array}$ & Kuala Lumpur & 2011 & $\begin{array}{l}\text { Dissemination of } \\
\text { knowledge (3) }\end{array}$ \\
\hline 13 & $\begin{array}{l}\text { An article "An Approach for Seismic Design in } \\
\text { Malaysia following the Principles of Eurocode 8" } \\
\text { in the IEM JURUTERA Monthly Bulletin [8] }\end{array}$ & - & 2011 & $\begin{array}{l}\text { Important publication } \\
(3)\end{array}$ \\
\hline 14 & $\begin{array}{l}\text { Sequel to Two-Day Course on Analysis and } \\
\text { Design to EC8 Demystified }\end{array}$ & Kuala Lumpur & 2012 & $\begin{array}{l}\text { Dissemination of } \\
\text { knowledge (4) }\end{array}$ \\
\hline 15 & $\begin{array}{c}\text { Two-Day Symposium and Workshop on } \\
\text { Earthquake Engineering in Malaysia and Asia } \\
\text { Pacific Region }\end{array}$ & Kuala Lumpur & 2012 & $\begin{array}{l}\text { Dissemination of } \\
\text { knowledge (5) }\end{array}$ \\
\hline 16 & Local M4.1 seismic activities detected & Temenggor Lake, Perak & 2013 & Seismic event (5) \\
\hline 17 & $\begin{array}{c}\text { An article "Recommended Earthquake Loading } \\
\text { Model for Peninsular Malaysia" in the IEM } \\
\text { JURUTERA Monthly Bulletin [53] }\end{array}$ & Kuala Lumpur & 2013 & $\begin{array}{l}\text { Documentation in } \\
\text { publication (1) }\end{array}$ \\
\hline 18 & $\begin{array}{c}\text { Two-Day Symposium and Workshop on } \\
\text { Earthquake Engineering in Malaysia and Asia } \\
\text { Pacific Region }\end{array}$ & Kuala Lumpur & 2013 & $\begin{array}{l}\text { Dissemination of } \\
\text { knowledge (6) }\end{array}$ \\
\hline 19 & $\begin{array}{l}\text { Two-Day Workshop on Recommended } \\
\text { Earthquake Loading Model in the Proposed NA } \\
\text { to EC8 for Sabah, Sarawak and Updated Model } \\
\text { for Peninsular Malaysia }\end{array}$ & Kuala Lumpur & 2014 & $\begin{array}{l}\text { Dissemination of } \\
\text { knowledge }(7)\end{array}$ \\
\hline 20 & IEM meeting and Standard writing workshop & Kuala Lumpur & 2014 & $\begin{array}{l}\text { Major meeting/forum } \\
\text { with stakeholders }(1)^{*}\end{array}$ \\
\hline 21 & $\begin{array}{c}\text { Two-Day International Seminar and Workshop } \\
\text { on Presentation and Reviewing of the Draft } \\
\text { Malaysia NA to EC8 }\end{array}$ & Kuala Lumpur & 2015 & $\begin{array}{l}\text { Dissemination of } \\
\text { knowledge }(8)\end{array}$ \\
\hline 22 & IEM meeting and Standard writing workshop & Kuala Lumpur & 2015 & $\begin{array}{l}\text { Major meeting/forum } \\
\text { with stakeholders (2) * }\end{array}$ \\
\hline 23 & $\begin{array}{c}\text { Two-Day Course on How to Utilise Our Proposed } \\
\text { EC8 Malaysia NA to Our Practising Consulting } \\
\text { Engineers }\end{array}$ & Kuala Lumpur & 2015 & $\begin{array}{l}\text { Dissemination of } \\
\text { knowledge (9) }\end{array}$ \\
\hline 24 & $\begin{array}{c}\text { Special issue "Developing Malaysian Design } \\
\text { Standards for Earthquake Resistance" in IEM } \\
\text { JURUTERA Monthly Bulletin [54] }\end{array}$ & - & 2015 & $\begin{array}{l}\text { Documentation in } \\
\text { publication }(2)\end{array}$ \\
\hline 25 & Local M5.9 earthquake & Ranau, Sabah & 2015 & Seismic event (6) \\
\hline 26 & $\begin{array}{l}\text { Kota Kinabalu, Sabah Town Council, mandated } \\
\text { seismic design with PGA of } 0.12 \mathrm{~g}\end{array}$ & Kota Kinabalu, Sabah & 2015 & $\begin{array}{l}\text { Interim enforcement of } \\
\text { seismic design }\end{array}$ \\
\hline 27 & $\begin{array}{l}\text { Special issue "Public Safety in Earthquake Event" } \\
\text { in IEM JURUTERA Monthly Bulletin [55] }\end{array}$ & - & 2016 & $\begin{array}{l}\text { Documentation in } \\
\text { publication (3) }\end{array}$ \\
\hline
\end{tabular}


Table A1. Cont.

\begin{tabular}{|c|c|c|c|c|}
\hline No. & Events & Location & Year & Remarks \\
\hline 28 & $\begin{array}{l}\text { IEM Standard meeting to go through the public } \\
\text { comments }\end{array}$ & Kuala Lumpur & 2016 & $\begin{array}{l}\text { Major meeting/forum } \\
\text { with stakeholders (3)* }\end{array}$ \\
\hline 29 & $\begin{array}{l}\text { A journal paper "Minimum loading requirements } \\
\text { for areas of low seismicity" in Earthquakes and } \\
\text { Structures [19] }\end{array}$ & - & 2016 & $\begin{array}{l}\text { Documentation in } \\
\text { publication (4) }\end{array}$ \\
\hline 30 & $\begin{array}{l}\text { Dialogue on The Proposed NA to MS EC8 on } \\
\text { Design of Structure for Earthquake Resistance }\end{array}$ & Kota Kinabalu, Sabah & 2016 & $\begin{array}{l}\text { Major meeting/forum } \\
\text { with stakeholders }(4)^{*}\end{array}$ \\
\hline 31 & $\begin{array}{l}\text { Special meeting with Sabah } \\
\text { seismologist/geologist }\end{array}$ & Kota Kinabalu, Sabah & 2016 & $\begin{array}{l}\text { Major meeting/forum } \\
\text { with stakeholders (5)* }\end{array}$ \\
\hline 32 & Draft Malaysian EC8 NA for public comments [9] & Kuala Lumpur & 2016 & $\begin{array}{l}\text { Major meeting/forum } \\
\text { with stakeholders }(6)^{*}\end{array}$ \\
\hline 33 & $\begin{array}{l}\text { WG1 meeting with Department of Standards } \\
\text { Malaysia (DSM) }\end{array}$ & Shah Alam, Selangor & 2016 & $\begin{array}{l}\text { Major meeting/forum } \\
\text { with stakeholders }(7) *\end{array}$ \\
\hline 34 & $\begin{array}{c}\text { National Consultation of the Draft Malaysian } \\
\text { EC8 NA by DSM }\end{array}$ & Shah Alam, Selangor & 2016 & $\begin{array}{l}\text { Major meeting/forum } \\
\text { with stakeholders }(8) *\end{array}$ \\
\hline 35 & $\begin{array}{c}\text { Seminar on Analysis of Torsional Actions in } \\
\text { Buildings }\end{array}$ & Kuala Lumpur & 2016 & $\begin{array}{l}\text { Dissemination of } \\
\text { knowledge }(10)\end{array}$ \\
\hline 36 & $\begin{array}{l}\text { WG1 study group meeting with Minister of } \\
\text { Science, Technology and Information }\end{array}$ & Kota Kinabalu, Sabah & 2016 & $\begin{array}{l}\text { Major meeting/forum } \\
\text { with stakeholders (9)* }\end{array}$ \\
\hline 37 & $\begin{array}{c}\text { A journal paper "A design spectrum model for } \\
\text { flexible soil sites in regions of low-to-moderate } \\
\text { seismicity" in Soil Dynamics and Earthquake } \\
\text { Engineering [31] }\end{array}$ & - & 2017 & $\begin{array}{l}\text { Documentation in } \\
\text { publication (5) }\end{array}$ \\
\hline 38 & Special four seismic experts meeting & Kuala Lumpur & 2017 & $\begin{array}{l}\text { Major meeting/forum } \\
\text { with stakeholders }(10) \text { * }\end{array}$ \\
\hline 39 & $\begin{array}{l}\text { Two-Day Workshop on Proposed Seismic } \\
\text { Analysis Methods for Regions of Low to Medium } \\
\text { Seismicity }\end{array}$ & Kuala Lumpur & 2017 & $\begin{array}{l}\text { Dissemination of } \\
\text { knowledge (11) }\end{array}$ \\
\hline 40 & $\begin{array}{c}\text { A conference paper "Intricacies of addressing } \\
\text { distant and local earthquakes in Malaysia in the } \\
\text { official design standard EC8 Malaysia NA" at } \\
\text { AEES 2017 [56] }\end{array}$ & Australia & 2017 & $\begin{array}{l}\text { Documentation in } \\
\text { publication }(6)\end{array}$ \\
\hline 41 & $\begin{array}{l}\text { Finalised Malaysian EC8 NA for public } \\
\text { comments }\end{array}$ & Kuala Lumpur & 2017 & $\begin{array}{l}\text { Major meeting/forum } \\
\text { with stakeholders }(11)^{*}\end{array}$ \\
\hline 42 & Publication of MS NA EN 1998-1: 2015 (2017) [2] & - & 2017 & Published standard \\
\hline 43 & Public forum on Malaysia NA to EC8 by DSM & Shah Alam, Selangor & 2017 & $\begin{array}{l}\text { Major meeting/forum } \\
\text { with stakeholders (12)* }\end{array}$ \\
\hline 44 & $\begin{array}{l}\text { A journal paper "Seismic Hazard and Response } \\
\text { Spectrum Modelling for Malaysia and Singapore" } \\
\text { in Earthquakes and Structures [20] }\end{array}$ & - & 2018 & $\begin{array}{l}\text { Documentation in } \\
\text { publication (7) }\end{array}$ \\
\hline 45 & $\begin{array}{c}\text { Two book chapters in Guideline on Design of } \\
\text { Buildings and Structures in Low-to-moderate } \\
\text { Seismicity Countries }[46,47]\end{array}$ & Hong Kong & 2018 & $\begin{array}{l}\text { Documentation in } \\
\text { publication (8) }\end{array}$ \\
\hline 46 & $\begin{array}{l}\text { Two-Day Symposium on Earthquake Resistant } \\
\text { Design of RC Buildings based on the EC } 8 \\
\text { Malaysia NA: From Loading Characterisation to } \\
\text { RC Detailing }\end{array}$ & Kuala Lumpur & 2018 & $\begin{array}{l}\text { Dissemination of } \\
\text { knowledge (12) }\end{array}$ \\
\hline 47 & $\begin{array}{l}\text { Two-Day Symposium on Earthquake Resistant } \\
\text { Design of RC Buildings based on the EC } 8 \\
\text { Malaysia NA: From Loading Characterisation to } \\
\text { RC Detailing }\end{array}$ & Kuching, Sarawak & 2019 & $\begin{array}{l}\text { Dissemination of } \\
\text { knowledge (13) }\end{array}$ \\
\hline
\end{tabular}


Table A1. Cont.

\begin{tabular}{|c|c|c|c|c|}
\hline No. & Events & Location & Year & Remarks \\
\hline 48 & $\begin{array}{c}\text { A conference paper “The Malaysian Seismic } \\
\text { Design Code: Lessons learnt” at NZSEE } 2019 \\
\text { Pacific Conference on Earthquake Engineering } \\
\text { (PCEE) [3] }\end{array}$ & $\begin{array}{l}\text { Auckland, New } \\
\text { Zealand }\end{array}$ & 2019 & $\begin{array}{l}\text { Dissemination of } \\
\text { knowledge (14) }\end{array}$ \\
\hline 49 & $\begin{array}{l}\text { Launching of www.QuakeAdvice.org website } \\
\text { (last assessed on } 28 \text { October 2021) [10] }\end{array}$ & - & 2020 & $\begin{array}{l}\text { Dissemination of } \\
\text { knowledge (15) }\end{array}$ \\
\hline 50 & $\begin{array}{l}\text { One-Day webinar on Online Tools for Earthquake } \\
\text { Resistant Design of RC Buildings based on the } \\
\text { EC8 Malaysia NA }\end{array}$ & Malaysia, Australia & 2021 & $\begin{array}{l}\text { Dissemination of } \\
\text { knowledge }(16)\end{array}$ \\
\hline 51 & $\begin{array}{c}\text { A journal paper "Fast Checking of Drift Demand } \\
\text { in Multi-Storey Buildings with Asymmetry" in } \\
\text { Buildings [45] }\end{array}$ & - & 2021 & $\begin{array}{l}\text { Documentation in } \\
\text { publication (9) }\end{array}$ \\
\hline 52 & $\begin{array}{l}\text { A journal paper "Site-Specific Response Spectra: } \\
\text { Guidelines for Engineering Practice" in CivilEng } \\
\text { [32] }\end{array}$ & - & 2021 & $\begin{array}{l}\text { Documentation in } \\
\text { publication }(10)\end{array}$ \\
\hline 53 & $\begin{array}{c}\text { 4-half day webinar on Analysis and Design of } \\
\text { Building Structures for Seismic Environment in } \\
\text { Malaysia }\end{array}$ & Malaysia & 2021 & $\begin{array}{l}\text { Dissemination of } \\
\text { knowledge (17) }\end{array}$ \\
\hline 54 & $\begin{array}{c}\text { A conference paper “Simplifying Eurocode } 8 \\
\text { Ductile Detailing Rules for Reinforced Concrete } \\
\text { Structures" at 17th World Conference of } \\
\text { Earthquake Engineering [39] }\end{array}$ & Sendai, Japan & 2021 & $\begin{array}{l}\text { Documentation in } \\
\text { publication (11) }\end{array}$ \\
\hline
\end{tabular}

* These are major meetings/forums. Frequent communications between group members took place throughout the whole process.

\section{References}

1. MS EN 1998-1:2015. Eurocode 8: Design of Structures for Earthquake Resistance_Part 1: General Rules, Seismic Actions and Rules for Buildings; Department of Standards Malaysia: Selangor, Malaysia, 2015.

2. NA-2017 to MS EN 1998-1:2015. Malaysian National Annex to Eurocode 8: Design of Structures for Earthquake Resistance-Part 1: General Rules, Seismic Actions and Rules for Buildings; Department of Standards Malaysia: Selangor, Malaysia, 2017.

3. Looi, D.T.W.; Tsang, H.H.; Lam, N.T.K. The Malaysian Seismic Design Code: Lessons learnt. In Proceedings of the 2019 Eleventh Pacific Conference on Earthquake Engineering, Auckland, New Zealand, 4-6 April 2019.

4. IEM Position Document 2005. Position Paper on Issues Related to Earthquake; The Institution of Engineers Malaysia (IEM): Selangor, Malaysia, 2007.

5. Hee, M.C.; Lam, N.T.K.; Tsang, H.H.; Looi, D.T.W.; Zaeem, A.Z.; Lim, E.P. Evolution of IEM Study Group. In Jurutera the Monthly Bulletin of the IEM; The Institution of Engineers Malaysia (IEM): Selangor, Malaysia, 2016; pp. 12-14.

6. Lam, N.T.K.; Balendra, T.; Wilson, J.L.; Venkatesan, S. Seismic loads estimates of distant subduction earthquakes affecting Singapore. Eng. Struct. 2009, 31, 1230-1240. [CrossRef]

7. Megawati, K.; Pan, T.C. Ground-motion attenuation relationship for the Sumatran megathrust earthquakes. Earthq. Eng. Struct. Dyn. 2010, 39, 827-845. [CrossRef]

8. Pappin, J.W.; Yim, P.H.I.; Koo, C.H.R. An approach for seismic design in Malaysia following the principles of Eurocode 8. In Jurutera the Monthly Bulletin of the IEM; The Institution of Engineers Malaysia (IEM): Selangor, Malaysia, 2011 ; pp. $22-28$.

9. Draft NA-2016 to MS EN 1998-1:2015. Draft Malaysian National Annex to Eurocode 8: Design of Structures for Earthquake ResistancePart 1: General Rules, Seismic Actions and Rules for Buildings; Department of Standards Malaysia: Selangor, Malaysia, 2016.

10. Quakeadvice. Available online: www.quakeadvice.org (accessed on 28 September 2021).

11. Dowrick, D. Earthquake Resistant Design and Risk Reduction, 2nd ed.; Wiley: New York, NY, USA, 2009 ; pp. 45-129.

12. Mulargia, F.; Stark, P.B.; Geller, R.J. Why is Probabilistic Seismic Hazard Analysis (PSHA) still used? Phys. Earth Planet. Inter. 2017, 264, 63-75. [CrossRef]

13. Tsang, H.H.; Wenzel, F. Setting structural safety requirement for controlling earthquake mortality risk. Saf. Sci. 2016, 86, 174-183. [CrossRef]

14. Paulay, T.; Priestly, M.J.N. Seismic Design of Reinforced Concrete and Masonry Buildings; John Wiley \& Sons, Inc.: New York, NY, USA, 1992; pp. 1-94, 639-661.

15. Tsang, H.H. Lessons learnt from the 512 Wenchuan earthquake: Perception of seismic risks. In Proceedings of the Australian Earthquake Engineering Society Conference, Ballarat, Australia, 21-23 November 2008. 
16. Burbridge, D.; Leonard, M.; Allen, T.; Collins, C.; Volti, T. The 2012 National Earthquake Hazard Map of Australia. In Proceedings of the Australian Earthquake Engineering Society 2012 Conference, Queensland, Australia, 7-9 December 2012.

17. FEMA450. NEHRP Recommended Provisions for Seismic Regulations for New Buildings and other Structures; Building Seismic Safety Council, National Institute of Building Sciences: Washington, DC, USA, 2004.

18. Fardis, M.N. Seismic Design Assessment and Retrofitting of Concrete Buildings Based on EN-Eurocode 8; Springer: Berlin/Heidelberg, Germany, 2009; pp. 1-46.

19. Lam, N.T.K.; Tsang, H.H.; Lumantarna, E.; Wilson, J.L. Minimum loading requirements for areas of low seismicity. Earthq. Struct. 2016, 11, 539-561. [CrossRef]

20. Looi, D.T.W.; Tsang, H.H.; Hee, M.C.; Lam, N.T.K. Seismic Hazard and Response Spectrum Modelling for Malaysia and Singapore. Earthq. Struct. 2018, 15, 67-79.

21. AS1170. 4-2007 Amd 2:2018 Structural Design Actions, Part 4: Earthquake Actions in Australia; Standards Australia: Sydney, Australia, 2018.

22. Pitilakis, K.; Riga, E.; Anastasiadis, A. Design spectra and amplification factors for Eurocode 8. Bull. Earthq. Eng. 2012, 10, 1377-1400. [CrossRef]

23. Pitilakis, K.; Riga, E.; Anastasiadis, A. New code site classification, amplification factors and normalised response spectra based on a worldwide ground-motion database. Bull. Earthq. Eng. 2013, 11, 925-966. [CrossRef]

24. Pitilakis, K.; Riga, E.; Anastasiadis, A.; Fotopoulou, S.; Karafagka, S. Towards the revision of EC8: Proposal for an alternative site classification scheme and associated intensity dependent spectral amplification factors. Soil Dyn. Earthq. Eng. 2018, $126,105137$. [CrossRef]

25. Seed, H.B.; Ugas, C.; Lysmer, J. Site-dependent spectra for earthquake-resistant design. Bull. Seismol. Soc. Am. 1976, 66, 221-243. [CrossRef]

26. Lam, N.T.K.; Wilson, J.L.; Chandler, A.M. Seismic displacement response spectrum estimated from the frame analogy soil amplification model. Eng. Struct. 2001, 23, 1437-1452. [CrossRef]

27. Tsang, H.H.; Chandler, A.M.; Lam, N.T.K. Estimating Non-linear Site Response by Single Period Approximation. Earthq. Eng. Struct. Dyn. 2006, 35, 1053-1076. [CrossRef]

28. Zhu, C.; Pilz, M.; Cotton, F. Which is a better proxy, site period or depth to bedrock, in modelling linear site response in addition to the average shear-wave velocity? Bull. Earthq. Eng. 2020, 18, 797-820. [CrossRef]

29. Tsang, H.H.; Chandler, A.M.; Lam, N.T.K. Simple Models for Estimating Period-Shift and Damping in Soil. Earthq. Eng. Struct. Dyn. 2006, 35, 1925-1947. [CrossRef]

30. Tsang, H.H.; Sheikh, M.N.; Lam, N.T.K. Modeling Shear Rigidity of Stratified Bedrock in Site Response Analysis. Soil Dyn. Earthq. Eng. 2012, 34, 89-98. [CrossRef]

31. Tsang, H.H.; Wilson, J.L.; Lam, N.T.K.; Su, R.K.L. A Design Spectrum Model for Flexible Soil Sites in Regions of Low-to-Moderate Seismicity. Soil Dyn. Earthq. Eng. 2017, 92, 36-45. [CrossRef]

32. Hu, Y.W.; Lam, N.T.K.; Khatiwada, P.; Menegon, S.J.; Looi, D.T.W. Site-Specific Response Spectra: Guidelines for Engineering Practice. CivilEng 2021, 2, 712-735. [CrossRef]

33. Wair, B.R.; DeJong, J.T.; Shantz, T. Guidelines for Estimation of Shear Wave Velocity Profiles; PEER Report 2012/08; Pacific Earthquake Engineering Research Center, University of California: Berkeley, CA, USA, 2012.

34. Looi, D.T.W.; Chiang, J.C.L. Seismic Experts Explain Key Technical Issues in the Draft of National Annex to Eurocode 8. In Jurutera the Monthly Bulletin of the IEM.; The Institution of Engineers Malaysia (IEM): Selangor, Malaysia, 2017 ; pp. $26-31$.

35. Kottke, A.R.; Rathje, E.M. Technical manual for STRATA; PEER Report No.: 2008/10; Pacific Earthquake Engineering Research Center, University of California: Berkeley, CA, USA, 2008.

36. Fardis, M. Current Developments and Future Prospects of The European Code for Seismic Design and Rehabilitation of Buildings: Eurocode 8. In Proceedings of the Thirteenth World Conference on Earthquake Engineering, Vancouver, BC, Canada, 1-6 August 2004.

37. MS EN 1992-1:2010. Eurocode 2: Design of Concrete Structures-Part 1-1: General Rules and Rules for Buildings; Standards Malaysia: Selangor, Malaysia, 2010.

38. Bisch, P. Eurocode 8. Evolution or Revolution? In Recent Advances in Earthquake Engineering in Europe. In Proceedings of the Sixteenth European Conference on Earthquake Engineering, Thessaloniki, Greece, 18-21 June 2018; Kyriazis Pitilakis. Springer: Berlin/Heidelberg, Germany, 2018.

39. Looi, D.T.W.; Tsang, H.H.; Lam, N.T.K. Simplifying Eurocode 8 Ductile Detailing Rules for Reinforced Concrete Structures. In Proceedings of the Seventeenth World Conference on Earthquake Engineering (WCEE2020), Sendai, Japan, 22 September1 October 2021.

40. Varsamis, C.D.; Papanikolaou, V.K. Evaluation of current Eurocode 8 provisions on R/C ductile wall design. Structures 2021, 33, 368-377. [CrossRef]

41. Wilson, J.L.; Wibowo, A.; Lam, N.T.K.; Gad, E.F. Drift Behaviour of Lightly Reinforced Concrete Columns and Structural Walls for Seismic Performance Assessment. Aust. J. Struct. Eng. 2015, 16, 62-74. [CrossRef]

42. Raza, S.; Tsang, H.H.; Wilson, J.L. Unified models for post-peak failure drifts of normal- and high-strength RC columns. Mag. Concr. Res. 2018, 70, 1081-1101. [CrossRef] 
43. Looi, D.T.W.; Su, R.K.L.; Cheng, B.; Tsang, H.H. Effects of axial load on seismic performance of reinforced concrete walls with short shear span. Eng. Struct. 2017, 151, 312-326. [CrossRef]

44. Menegon, S.J.; Wilson, J.L.; Lam, N.T.K.; Mcbean, P. RC Walls in Australia: Seismic Design and Detailing to AS 1170.4 and AS 3600. Aust. J. Struct. Eng. 2017, 19, 67-84.

45. Khatiwada, P.; Lumantarna, E.; Lam, N.T.K.; Looi, D.T.W. Fast Checking of Drift Demand in Multi-Storey Buildings with Asymmetry. Buildings 2021, 11, 13. [CrossRef]

46. Lumantarna, E.; Mehdipanah, A.; Lam, N.T.K.; Wilson, J.L. Methods of structural analysis for buildings in regions of low-tomoderate seismicity. In Guideline on Design of Buildings and Structures in Low-to-Moderate Seismicity Countries. Professional Guide: PG-002; Lam, N.T.K., Chan, T.M., Eds.; Chinese National Engineering Research Centre for Steel Construction (Hong Kong branch), The Hong Kong Polytechnic University: Hong Kong, China, 2018; pp. 45-68.

47. Looi, D.T.W.; Lim, E.P.; Hee, M.C. A case study of code compliant design of buildings in regions of low-to-moderate seismicity. In Guideline on Design of Buildings and Structures in Low-to-Moderate Seismicity Countries. Professional Guide: PG-002; Lam, N.T.K., Chan, T.M., Eds.; Chinese National Engineering Research Centre for Steel Construction (Hong Kong branch), The Hong Kong Polytechnic University: Hong Kong, China, 2018; pp. 99-112.

48. Booth, E. Future Directions for Eurocode 8. In Proceedings of the Second European Conference on Earthquake Engineering and Seismology, Istanbul, Turkey, 25-29 August 2014.

49. Baker, J.W. Conditional mean spectrum: Tool for ground-motion selection. J. Struct. Eng. 2011, 137, 322-331. [CrossRef]

50. Horspool, N.; Gerstenberger, M.C.; Elwood, K.J. Risk Targeted Hazard Spectra for Seismic Design in New Zealand. In Proceedings of the NZSEE 2021 Annual Conference, Christchurch, New Zealand, 14-16 April 2021.

51. Tsang, H.H.; Daniell, J.E.; Wenzel, F.; Wilson, J.L. A Universal Approach for Evaluating Earthquake Safety Level Based on Societal Fatality Risk. Bull. Earthq. Eng. 2020, 18, 273-296. [CrossRef]

52. Booth, E. Future Directions for Eurocode 8. In Proceedings of the Seventeenth World Conference on Earthquake Engineering (WCEE2020), Sendai, Japan, 22 September-1 October 2021.

53. Looi, D.T.W.; Hee, M.C.; Tsang, H.H.; Lam, N.T.K. Recommended earthquake loading model for Peninsular Malaysia. In Jurutera the Monthly Bulletin of the IEM; The Institution of Engineers Malaysia (IEM): Selangor, Malaysia, 2013; pp. 6-20.

54. Chiang, J.C.L. Special Issue: Developing Malaysian Design Standards for Earthquake Resistance. In Jurutera the Monthly Bulletin of the IEM; The Institution of Engineers Malaysia (IEM): Selangor, Malaysia, 2015.

55. Chiang, J.C.L. Special Issue: Public Safety in Earthquake Event. In Jurutera the Monthly Bulletin of the IEM; The Institution of Engineers Malaysia (IEM): Selangor, Malaysia, 2016.

56. Chiang, J.C.L.; Looi, D.T.W.; Hee, M.C. Intricacies of addressing distant and local earthquakes in Malaysia in the official design standard EC8 Malaysia NA. In Proceedings of the Australian Earthquake Engineering Society 2017 Conference, Canberra, Australia, 24-26 November 2017. 